


\section{Irish on the walls: the branding of a language}

BY: Gabriella Rava

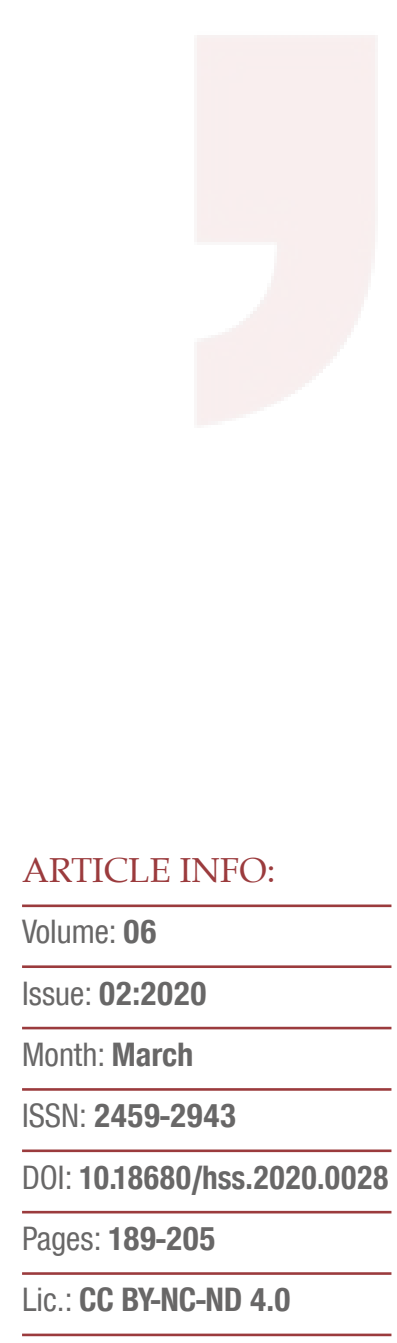

KEYWORDS:

Irish, branding

murals

tourism

ideology

\section{ABSTRACT}

$\mathrm{B} y$ the time the Belfast City Council launched a new logo

B in 2007, rebranding Belfast had become a central issue. The symbolic center of Belfast, the City Council building, presents itself as a post-modern and fully globalized space, neutralizing the memory of an area stigmatized by decades-long violence known as The Troubles. Like other cities with a traumatic past, such as Berlin, Belfast tries to promote itself as a modern and lively place, well aware of the importance of exploiting memory as a tourist attraction. The article examines the Irish language's resemantization in Belfast, particularly in the Gaeltacht quarter area, during and after The Troubles. Based on a paper by Siun Carden (2017), the article tries to connect the core of the author's observations to language's phatic function. The idea is that the contemporary branding of Irishness through the use of the Irish language on Belfast's murals works as an effective mythomoteur, a concept comparable to the mythe projectif elaborated by Bertrand (2019) in the case of Paris's rebranding.

\section{A new logo for a 'new' city}

This article concerns the recent past and the present image of the city of Belfast. Adopting a semiotic approach, we examine the ideologies underlying Belfast's rebranding strategies, from the new city logo to the redefinition of its historical and cultural heritage and its highly publicized muralism. Belfast, the capital of Northern Ireland, has been studied as an example of a divided city in several works (see Bollens 2012). The ethno-nationalist conflict between the Catholic nationalists (republicans) 
and the Protestant unionists (loyalists) named The Troubles broke out in 1968 and ended in 1998 with the Good Friday Agreement and the subsequent peace process. The British Army also took part in the guerilla type conflict (Kennedy-Pipe 1997), which mainly involved bombing attacks and target shootings. The Troubles left more than 3500 people killed and a still segregated country, with sporadic acts of violence occurring even after the peace process began. At the beginning of the 2000s, Northern Ireland's violent image necessitated a drastic revamping, if only to revive its crippled tourist trade. The need to convey the image of an attractive and peaceful new Belfast internationally meant that the Northern Ireland capital had to redefine itself as a brand.

In 2007, thanks to a London branding consultancy, the Belfast City Council adopted a new logo, a heart-shaped letter B (Moore 2016), which proved hugely successful. Its design was quite challenging. Choosing a symbol or a particular color can become a highly controversial matter in the knotty context of Belfast and the entire Northern Ireland, where despite 22 years of formal peace following the Good Friday Agreement, a symbolic and memory war still exists. To avoid possible controversy, a multi-colored palette - comprising a total of sixteen colors - was chosen, as well as different taglines, playing with the sound of the letter B as 'be' (to be).

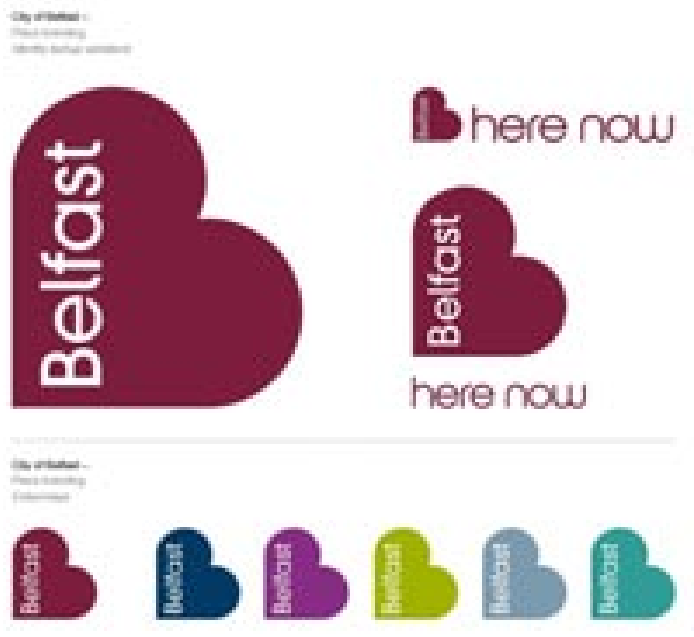

In his study on Belfast's rebranding, Moore underlines its essential character as a marketing investment. As in the case of the branding of Skopje, studied by Graan, the actual audience is tourists to whom the site must convey an idea of "modernity and dynamism, its sophisticated pleasures, and its 'European' character' (Graan, in Moore 2016: 143). All the same, the opinion of the local people was taken into account. The project team responsible for the rebranding was perfectly aware of the need to ensure the local people appreciate the city's revamping and, ideally, actively promote the new values associated with it to both foreigners and the new generation. They actively pursued the engagement of the community, the youth, and the tourism sector personnel. ${ }^{1}$ As Moore points out, the aim of involving all these in the rebranding process was to avoid potential discord about which symbols and colors will represent the city. Three actors could put forward diverging perspectives: the Republican/Catholic and the

\footnotetext{
${ }^{1}$ The same effort in collecting inputs and the public feelings towards the image of Belfast has been put in place more recently, in 2017, when a new logo has been launched by the City Council. The new logo is shaped on the image of the city from a satellite view, and once again uses a multicolored palette.
} 
Loyalist/ Protestant communities, and the City Council. These two historical communities are rooted in longstanding symbolic traditions, visible almost everywhere in Belfast streets, walls, lamposts, etc. In particular, color plays a crucial demarcating role: the red, white, and blue of the flags marking the Loyalist areas are opposed to the green, white, and orange of the Republican ones. The communities' colors feature prominently in their war over values and memories and play a critical role in their identity displays.

The City Council's new logo aimed to forge a new city identity, distant from these historically rooted symbols. The sectarianism associated with the variant chromatic traditions was to be avoided at all costs if the rebranding campaign was to be successful. Quite clearly, the ideological intention was to promote a new image of Northern Ireland, consistent with an economic rationale that sought its integration into the globalized scenario. The values promoted by Belfast's rebranding appertain to what Moore defines as "postsectarian citizens," a reality yet to come, a dreamed collective where "the dignity of industrial work has been replaced by the playfulness and flexibility of 'the new economy'"' (Moore 2016: 159).

\section{The issue of historical representation}

The City Council was the key social actor promoting the refurbishing of Belfast's complex urban fabric. Being the epicenter of modern Belfast, the powerhouse of political politics and urban strategy, it is set in an impressive building, facing Donegall PI and Royal Avenue's shopping streets. Similar in its aspect to the centers of many cities worldwide, Belfast's heart is nowadays a pleasant and dynamic place, making it difficult to imagine the Troubles' traumatic past. There are no specific references, no plaques helping the visitors to ruminate over Belfast's harrowing recent history; commemoration concerns only events unrelated to the sectarian conflict. Amongst the many statues and monuments marking the City Hall area, the Titanic memorial and the Garden of Remembrance with the Cenotaph stand out, designating Belfast's center as a mourning place par excellence. There is no space, however, for forms of commemoration diverging from those sanctioned by the State. In contrast with Belfast's working-class areas, which are firmly attached to their specific idea of identity, the city center is the critical site of the global financescape and the unified and reconciled version of Northern Ireland.

Andreas Huyssen (2003) has noticed a similar phenomenon in postwar Berlin, another city with a traumatic past. The German capital's center was and still is the city's political and economic heart, whose globalized and post-modern image leaves no space enabling the remembrance of its conflict-ridden historical heritage. In theory, there are two alternatives: either the city center becomes the site of an institutionalized, non-conflictual memory, or the vexing past is radically erased. The outcome of both policies is 
an atmosphere of neutrality. In this respect, Berlin is an especially enlightening case: the post-unification architecture of Potsdamer Platz, the city's symbolic center, is built on a space left vacant for a long time after the war, on account of being the site of the Nazi institutions which ruled over Germany and occupied Europe. Postwar Germany's inability to process collective guilt through a positive historical narrative had led to a refusal of that space in the reconstructed Berlin. This empty center's paradox was highly symbolic, while, thanks to the emptiness, it was unintentionally turned into a marked site, appropriately called the prairie of history (Mazzucchelli 2010).

Both the policies mentioned above are ideologically marked. In the first case, we have the production of an inarticulate space that demonstrates a refusal to deal with the burden of the past. In the second case, the city center's reconstruction involves adopting the model of the postmodern city. This latter is one of the many attempts to erase or rework the traces of history. A sanitation practice felt as indispensable for creating a space appropriate to the neutrality of an economic and future-oriented environment. This kind of urban renovation comes close to Baudrillard's concept of hyperreality (Baudrillard 1981). In this case, though, the sense of inauthenticity arises not from falsifying the city's aspect but through the city's overwriting by globalization. Peculiar, new forms of memorialization are an integral part of this overwriting. For example, the Titanic memorial placed in the Belfast City Hall gardens cannot claim any representative function. The ship was built in the Belfast shipyards, the now socalled Titanic Quarter, on whose site the museum Titanic Belfast opened in 2012. However, the event commemorated by the memorial took place in the middle of the ocean, decisively far away from Belfast.

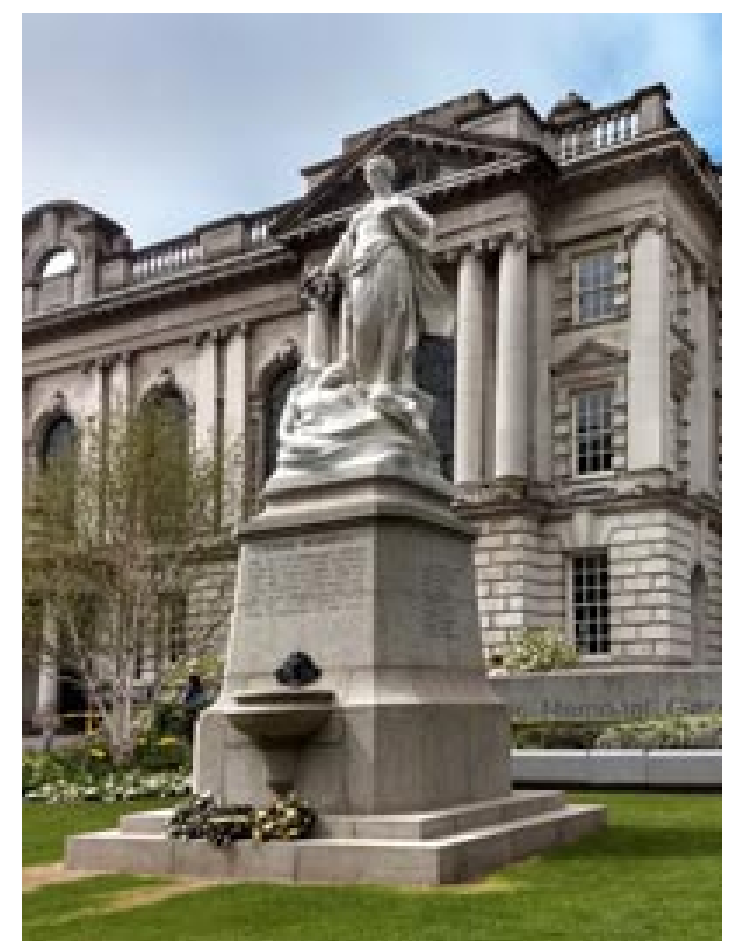

The evident impossibility to 'commemorate' the tragedy in the 'actual' place of the occurrence imposed the need to find an appropriate memorial space. The final choice of locale breaks with the memorials and monuments' general conception as traces directly related to the original site in which the commemorated event took place or is supposed to have taken place. The weakening of the indexical relationship between the memorial and the memory it evokes fosters the virtualization of the real event (i.e., the shipwreck), thus inducing its transformation into a universal symbol. This process pertains to the current deterritorialization of memory through different media, which shape it following the norms of a globalized, typically 
transnational, and multimedia memory system, just as it happened recently with the Holocaust (Rigney 2018).

Because of its global nature, Belfast's modern center can be perceived as a non-place (Augé 1992). The neutrality and abstraction associated with non-places are also found in the postmodern centers of Western cities. The non-place, usually described as nonrelational, unbound from any sense of identity, is also non-historical. Its inability to integrate other times and memories is also the inability to integrate other preexisting spaces and converse with them. Emblematic of the post-modern era, non-places are spaces of transition, like airports or shopping malls, but also more dramatic realities like the refugees' camps. Considering how they deal with time and history, we can perceive both non-spaces and postmodern city centers as 'flat' sites. Augé describes nonplaces as totally focused on the present, due to their amusement and consumption function, making them spaces shaped almost exclusively on esthetic values.

The same can be said of the way memory is treated in Belfast's city center. The political objective of creating an official lieu de mémoire (Nora 1989), befitting the institutionally sanctioned identity, requires the exclusion of alternative or counter-narratives. This exclusion turns the memory celebrated by the City Hall monuments into a form of frozen history. The voice of the past is esthetically fixed in the statues' timelessness and the Cenotaph grandeur. The representational choices made by the political authorities aim to 'domesticate' the past, avoiding the contradictions that collective memory inevitably entails. Therefore, what we experience is a depthless temporal dimension. In this sense, Belfast's center is non-historical, precisely like Augé's non-places. The architectural and figurative styles adopted do not relate to local identity but to a classic style, which embodies a non-controversial version of history, expressed in a universal language.

Monuments and memorials form a fundamental part of urban planning. Being symbols of the political elites (Bellentani 2017), they play an essential role in what Bellentani calls 'transitional societies,' as Northern Ireland has been until recently and, to a large extent, continues to be. Bellentani points out that semiotics and cultural geography have traditionally focused on monuments' intended meanings and functions from the elites' perspective. What the Belfast case-study tries to demonstrate, however, is how the local communities' cultural heritage can work as an ideological discourse as much as the institutional memory discourse. The policy-makers' ability to appreciate certain urban spaces' importance to promote some specific interpretation of the past is directly related to the city's conception as a brand. Like Augé's non-places, the center of Belfast can become a text, in a semiotic sense, ${ }^{2}$ and a primarily visual text, at that. The City Hall building has been relaunched as a successful touristic brand, as evidenced

\footnotetext{
2 Understanding the city as a text relates to the turn of semiotics from the sign to the text as an object of investigation. An isolated sign can only be analyzed on an abstract level, since reality involves a complex interaction of multiple signs, i.e., a text, in the etymological meaning of woven.
} 
by the merchandise sold (the Visit Belfast center overlooks the building's square) on websites. The proliferation of images that anticipates the visitors' discovery of the city echoes again Baudrillard's idea of hyperreality, according to which iconic imagery acquires a sense of authenticity that feels more real than the reality it stands for.

So far, we have examined the ideological underpinnings of Belfast's rebranding from the perspective of institutional policy. In the following section, we focus on how the Irish language and culture are represented during and after the Troubles.

\section{How to promote tradition: the Gaeltacht case}

West Belfast is known as a Catholic area par excellence. The recently established Gaeltacht Quarter appears like an Irish fortress in the city landscape. Being a working-class neighborhood, Gaeltacht Quarter has experienced a lot of violence during the Troubles because of its closeness to Shankill Road's protestant area. The high concentration of murals, flags, and other nationalist insignia work as a reminder of Belfast's tragic past and a still vital representation of the local population's identity. In opposition to the city center, the Gaeltacht quarter is an area proud of offering its houses' surfaces to the Troubles' representations and the recent past sufferings. The conflict and the sectarianism of Belfast's working-class zones can be read through the murals and the walls themselves, still surviving markers of the two communities' residential segregation. Walls, peace-lines, and barbed wire are present almost everywhere, at once territorial markers and barriers for maintaining peace (McAtackney 2011), delineating a place that appears authentic and genuine in tourist's eyes compared to the 'ordinary' appearance of Belfast's center. The rebirth of tourism in Northern Ireland after the Good Friday Agreement has given a powerful impetus to a new way of reading these partisan emblems. Considered as political devices during the thirty-year long conflict, they became heritage signs in the post-conflict period. This change has been outlined by Siun Carden (2017), who focuses on how the Irish language has come to acquire a different social and political status in the Gaeltacht quarter.

During the Troubles, the Irish language experienced a revival due to the Republican community's systematic promotion of Gaelic culture and tradition and the broad international exposure of the Blanketmen's protest at the beginning of the 1980s. ${ }^{3}$ Carden suggests that, in the beginning, the Irish language functioned as a political tool marking the Catholic-Republican territory as a nationalist space, all the while signaling the un-

\footnotetext{
The Blanketmen were the paramilitary Republican prisoners detained in the so-called H-Blocks, because of their shape, in the Long Kesh prison, who went on a strike in order to obtain the restoring of their political status, which had been suspended in 1976. The last phase of the protest, the hunger strike, led to the death of many prisoners, amongst them the republican hero Bobby Sands. Their name derives from being scantily clad with just a blanket because they refused to wear the prison uniform (see Feldman 1991).
} 
desirability not only of the Protestants but above all the British soldiers sent to 'solve' the conflict between the two rival communities. ${ }^{4}$ In structuralist terms, Irish was opposed to English, while Irish acquired its specific meaning because of this opposition. Messages conveyed by the Irish language couldn't be understood either by the unionists (mainly) or by the British troops and by many members of the Republican community. Irish was a pure signifier, immediately recognizable but virtually unintelligible for all these people. That use of Irish produced an effect of reification. It was perceived as a pure thing, obstructing rather than facilitating communication; nevertheless, the language gained its awareness from its opposition to English.

By the end of the conflict, the necessity of being understood grew stronger. Since the explosive media attention for the Blanket Protest and the Hunger Strike, which led to one of the leaders, Bobby Sands, elected as MP shortly before his death, the republican strategy had been slowly changing from the armed struggle to the political engagement. Sinn Féin, the Irish republican party, became an important actor in policymaking and the peace process. This changed situation also affected the Irish language's status and prospects as there was a new place for it in post-conflict Northern Ireland. The presence of the murals and their growing resonance as a tourist attraction also played a crucial role. Since the recovery of Northern Ireland's tourism, it was no longer possible to consider the Irish language in a sectarian way. ${ }^{5}$ A propaganda strategy and seeking 'international' support have been latent right from the beginning of nationalist muralism. However, at the end of the conflict, this approach turned into a new political direction, no longer at the urging of the previous period's pressing demands. It turned instead into a social and community remembering, often aimed at justifying IRA's violent position through the image of an Ireland prisoner of the colonialist United Kingdom, opposed to the protestant version of a land always under siege. In this panorama, the importance of promoting the glorious past, mostly a mythical one, and all the aspects related to Ireland's Gaelic soul came to be a fundamental step in constructing nationalist rhetoric, where language held a central place.

The conflict of memories found its ground in the areas which had suffered the most violence, the working-class neighborhoods, culturally and visually distant from the center and its institutional memory. As shown above, this latter creates the space of a unified country, whose grief has been erased by the commercial energy of a growing

\footnotetext{
4 The long history of conflict and violence in Ireland, dating back to remote times, has been labelled as The Irish problem since the XIX century. During the Troubles, the British government believed deploying the army could put an end to the conflict. The Catholic community initally welcomed this move, but subsequently, the role of the British Army in the conflict became highly controversial. British soldiers were seen as modernday 'colonizers' of the Irish land and targeted by paramilitary attacks (see Kennedy-Pipe 1997).

${ }^{5}$ Northern Ireland's tourist income has significantly increased, particularly in teh cities of Belfast and Derry/Londonderry, making the murals and everything connected to the Troubles major attractions. Many studies have investigated the phenomenon, e.g. Skinner and Jolliffe (2017), Crooke and Maguire (2019).
} 
nation, and mourning occurs in a controlled normative framework. Nevertheless, politics is not alien to initiatives involving the communities and their remembering. The recent murals on which the Irish language appears are the products of a double objective: on the one hand, they are the result of the state policy's recommendation that the two communities must cultivate a new, violence-free visual culture; on the other hand, they reflect the republicans' tactical adaptation to the changed context of the postconflict political arena.

Murals and other nationalist symbols, but also more complex identity manifestations, as the Féile an Phobail, ${ }^{6}$ all highlight the need to consider the Irish language as a local peculiarity, yet harmoniously integrated into the wider Northern Ireland society. It is a way of conceiving the language in a glocal perspective, which tries to save the identity of a peripheral reality and, at the same time, promote it as evidence of modernization and commercial success. Irrespective of this rhetoric's actual impact in the global markets, it is relevant to examine how it has contributed to the visual look of the recent murals and the Irish language's semiotic status.

Firstly, it is striking how hard it is to find murals with slogans written exclusively in the Irish language. As a rule, Irish inscriptions are accompanied by their English translation, to be widely legible, following the present-day nationalist agenda's political exigency. The Irish's social status is, evidently, no longer defined in terms of its opposition to English. Secondly, the writing of Irish has acquired a sort of decorative aspect. While communicating something, the signifier is once again more important than its signified.

Frequently, slogans on the murals are written directly in English but in fonts typically associated with what can be called an air of Irishness. Carden observes that these fonts are based on typefaces "used to represent the Irish language until the mid-twentieth century" (Carden 2017: 244). Because of their strong association with Ireland and Irish, they continue to be used in a wide variety of merchandise. This new trend has turned Irish into a visual sign, behaving more like an icon than a symbol. The arbitrariness of the verbal sign is not perceived; the fonts are naturally read as the real essence of Ireland, according to the myth-making mechanism described by Roland Barthes (1957). Here the visual aspect of writing, the fonts used on the murals, gives rise to a new signification, i.e., Irishness.

The historical dimension inscribed in the fonts, connected with the typefaces society uses at a particular time, is almost completely lost in the final signification, appearing as entirely natural. The notion of Irishness has a confused set of associations. However, it is so successful in presuming a pure and enduring essence of Ireland and its people that everybody, even tourists, can grasp it. The fonts' strategic use demands

\footnotetext{
${ }^{6}$ The Féile an Phobail (meaning the community's or the people's festival) is an arts and cultural organization set in West Belfast, organizing different celebrations, focusing particularly on the promotion and preservation of the Irish language.
} 
neither knowledge of the local tradition nor the work of translation into another code. Irish is still perceived as a language, conveying perhaps a nebulous meaning. Yet, its perception as a tongue is undermined due to the foregrounding of its iconic aspect that negates the arbitrariness characterizing the linguistic system.

The success in using Irish in the Gaeltacht quarter as a modern brand has relaunched West Belfast's area as the city's dreamed authentic soul. Although superficial, Gaeltacht's aura of traditionalism gave it a competitive advantage as a tourist destination over the anonymous center. In contrast to the universalism projected by the City Hall's architecture, the Gaeltacht imagines itself as the local heritage's rebirth site. The Irish inscriptions on the walls signify the public declaration and affirmation of a distinct identity caught in the collective memory of struggles that still cuts off certain Belfast areas from the rest of the city. The decorative use of Irish on the murals, a sort of frill which exalts the signifier's power, has vital ideological relevance, to be explored in the following section.
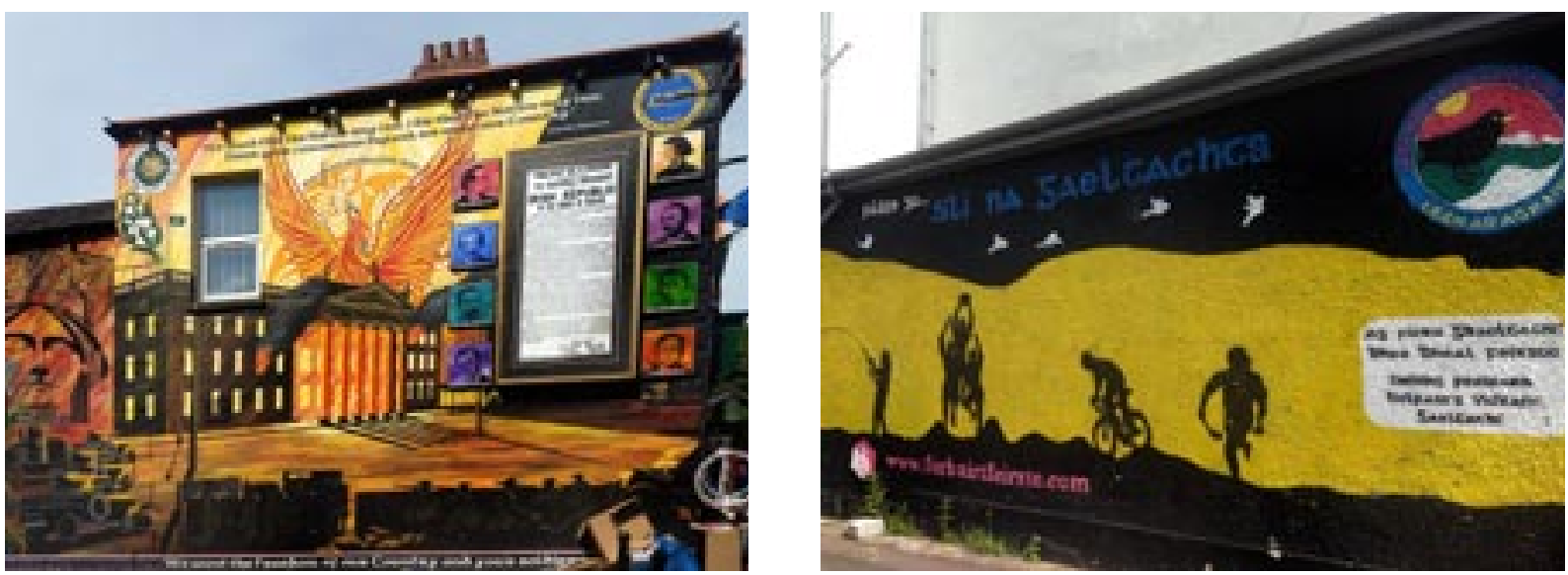

\section{The Republican murals: an example of the phatic function?}

In an article dedicated to enunciation and dialogue, Émile Benveniste (1970) points to the case Malinowski calls phatic communion (1923), whereby conversation is not driven by a leading interest in the content of the information exchanged. Malinowski perceives here a way of using language that prioritizes the psychosocial function of creating and maintaining intersubjective contact. He has in mind certain forms of courtesy typical of specific social environments, or even the case of rhetorical questions, where speaking seems to be devoid of any particular meaning except that of reaffirming the social relationship between two or more interlocutors. The phatic communion highlights language's social character, meaning its capability to build and reinforce human coexistence. Specifically, it reintroduces the importance of the practical aspects of lan- 
guage. The actual information exchanged in speech is almost null, creating the effect of a highly conventionalized enunciation, of a signifier folded onto itself. This sociopragmatic function of language reinforces the naturalization phenomenon, just as the ideological structure at the basis of the notion of Irishness. The phatic communion has proven to be extremely effective in maintaining and reinforcing social bonds, as the daily social interaction frequently involves such mechanical components. This linguistic function works thanks to contextual inferences from the specific situation in which the exchange occurs; nevertheless, these latter are so introjected in the interlocutors' habits not to be discerned, as an automatic process, similar to how we read Irish fonts nowadays.

Malinowski's intuitions have been developed further by Roman Jakobson, who defined the phatic function as one of the six functions of language (1960). ${ }^{7}$ Following Malinowski, Jakobson insists on the specific purpose of creating a contact between the sender and the receiver, partially independent of what the message says. Coming back to the use of Irish on Belfast's nationalist murals, it is interesting to see how the phatic function model applies to the relationship between the observers and the creators of some of the most recent of them, appearing in the Gaeltacht quarter.

In earlier nationalist murals, we find an entirely different use of Irish. In their case, the relation observer-creator can be described in terms of Jakobson's metalinguistic function. The latter involves the message's focus on the interlocutors' code (i.e., on the language itself). For example, this happens when the Irish or the fonts connected with it are employed to refer directly to themselves, mostly concerning the Irish's social status in Northern Ireland. Despite the similar effect of the signifier folded onto itself, this function requires the receiver's specific knowledge and awareness of the code used and the position occupied by the Irish language in present-day Northern Ireland. A metalinguistic sensibility was highly active during the Blanketmen protest and the subsequent Hunger Strike, since the republican prisoners in the H-Blocks used to write the messages smuggled out of prison in Irish and even to teach some classes illegally (McAtackney 2014). Quite probably, this linguistic awareness is no longer valid nowadays. As described above, the exigency of turning Irish into a brand and improving its possibilities of success in the job and tourist market requires not necessarily the consciousness of the language's real status or the competence to speak and understand it. It wouldn't be understandable otherwise that on the Gaeltacht's murals, in an area that proudly proclaims its distinct identity, Irish stands along with English, or even English seems to replace it by appearing in Irish fonts.

\footnotetext{
7 The six functions of language identified by Roman Jakobson are the referential, the poetic, the emotive, the conative, the metalinguistic and the phatic. See his article Linguistics and poetics (in T.A. Sebeok, ed., Style in language,1960) which is based on a conference speech he gave at the Indiana University, in 1958.
} 
Apart from the growing importance of tourism and the political clout of Sinn Féin, it should be remarked the renowned tendency from the nationalist murals, already operating during the first wave of the republican muralism in the 1980s, to depict a series of personalities and ideological struggles to which the community is supportive. Carden defines it as an 'international framework,' addressing a public other than the locals and, therefore, suggesting a different horizon of expectation (Jauss 1982). The growing adoption of English instead of Irish can also be explained as an ideological turn, offering a shallow entrance into a supposed Gaelic tradition to a culturally distant audience. But it is a political turn as well. The Gaelicization of English is often accompanied by slogans in other languages, mostly Arabic, supporting the Palestine cause, or marginalized languages like Basque or Catalan, to underline that Irish's social and political position is in a comparable danger. The paradox stands in the decision to manifest this awareness in the language Irish used to be opposed to, thus weakening this opposition and the sensibility towards the code's vulnerability. To gain institutional recognition is the basis on which the relaunch of Irish in Northern Ireland would be possible, yet with an international and cosmopolitan nuance. That is at least the nationalist demand of Sinn Féin's political agenda.

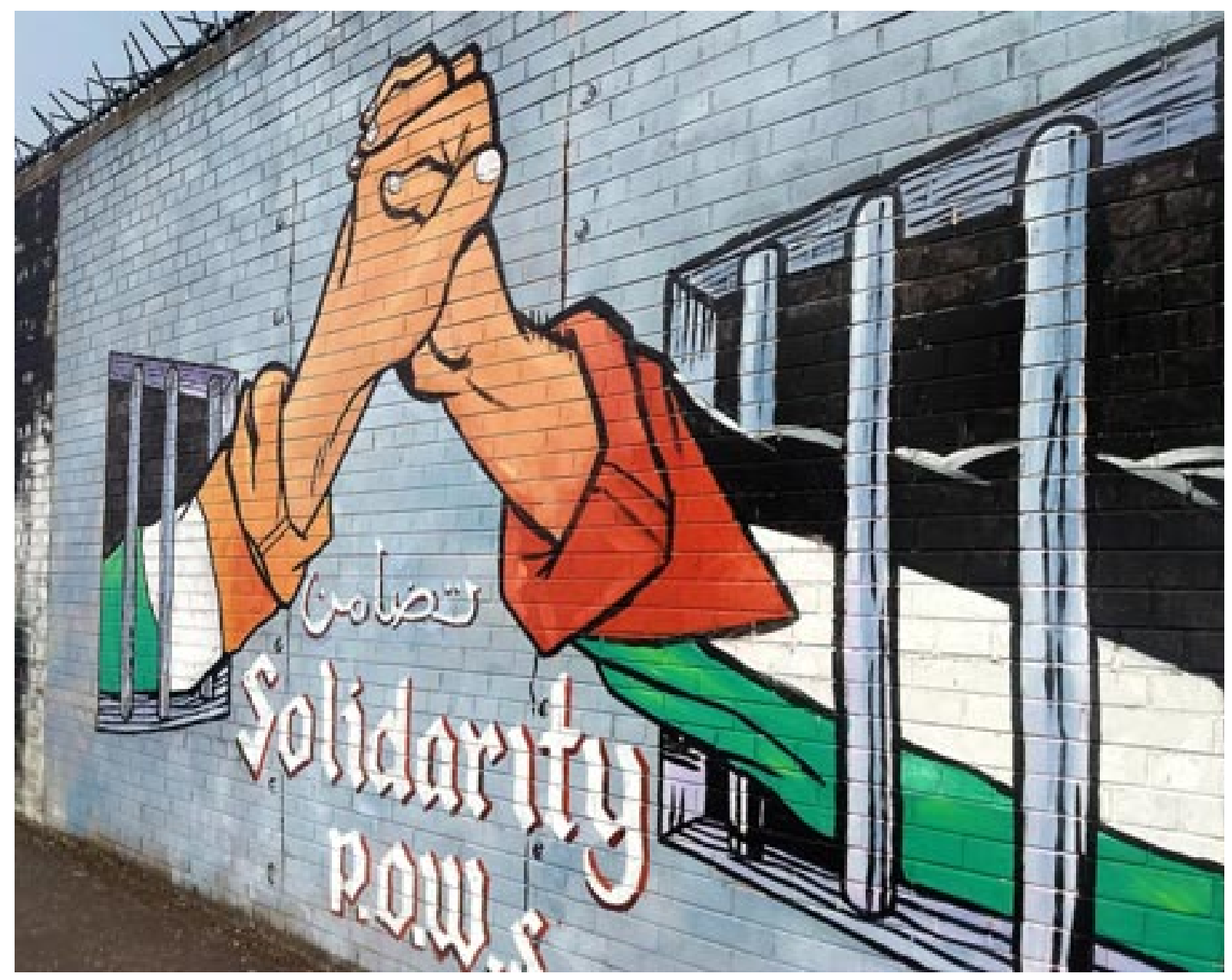




\section{A linguistic mythology}

\subsection{Irish in Northern Ireland: an example of mythomoteur}

We can approach the use of Irish as an iconic sign based on Anthony D. Smith's concept of the mythomoteur (1986). ${ }^{8}$ The mythomoteur, a myth that provides the foundation of a particular ethnic and national community, reveals in its etymology the dynamic nature of the myth, conceived not as a static symbol but as an active process evolving with the change of the social and historical context in which it flourishes and grows (Forker and McCormick 2009). This interpretation of the myth allows for the emergence of new values and contexts, despite the apparent endurance of mythical representations. The evolution in the ways of performing the Irish identity, briefly traced in the preceding sections, obeys a similar mechanism, passing from depicting a segregated and fully self-conscious, freedom-fighting community to the proud portrayal of an imagined modern and cosmopolitan one. Nowadays, the Irish language wants to represent itself as the paradox of a local identity seeking its integration into the global economy. In this context, marketing one's not so distant and traumatic past to tourists looking for strong emotions has become a profitable opportunity, as demonstrates the phenomenon of dark tourism. The 'taste of Irishness' promised by places like the Gaeltacht quarter works as a visual hook for the visitors while condensing the community's ideological strategy. In his study of the Irish communities' visual displays, Neil Jarman (1997) examines the variety of subjects depicted in contemporary Northern Ireland's murals and their enhanced attractiveness compared to earlier murals. A broader, international address and the mediation of global media make it necessary to consider the murals' making as a complex ideological tool much more than a simple expression of ethnic identity or a contested space's sectarianism.

\subsection{The myth of the city or the city as a myth}

We can read both Belfast's rebranding and the resemantization of the Irish language under the sign of a campaign to promote another collective image of Belfast mainly addressed to the international audience but simultaneously aimed to solicit a utopian scenario for the local people. In the previous section, the notion of $m y t h$, in its variant known as mythomoteur, is suggested as a useful tool in understanding the ideological underpinnings of the current relaunch of the Irish language. To clarify further this suggestion, we will turn to the case of another capital, Paris.

In 2015, a series of urban renovation projects was launched to refurbish the city's profile called Réinventer Paris (Bertrand 2019). This operation, precisely as it happened

\footnotetext{
${ }^{8}$ The concept of mythomoteur is extensively used by Anthony D. Smith in his The ethnic origins of nations (1986). The term had been employed earlier by other authors but entered common usage thanks to Smith's works.
} 
with post-conflict Belfast, required creating a powerful collective imagination capable of engaging peoples' desires and aspirations. Bertrand proposes the notion of mythe projectif to describe the campaign's atmosphere, which stands for the paradox of a mythical narrative not looking at the past of a nation, as it usually works, but turning its attention towards the future, in a sort of 'anticipated construction.' Like the Irish of the present-day Gaeltacht, the language of a future utopian community, the linguistic aspect involved in the Réinventer Paris project plays a fundamental role, to the point that, in Bertrand's opinion, it is possible to talk about a new language. At the basis of the narratives about the urban interventions, the French language is again a utopian language. However, the idyllic effect here is created not through the change of the socio-political context in which the language operates but by using it in specific ways. The oxymoron, the acronym, the metaphor, along with others, are examples of a plethora of figures of speech mobilized to create this dreamful language of collective enthusiasm, working towards a more or less viable future.

The Irish on the murals and the French of a renovated Paris share the disturbing reality of the non-existence of the social model they promote, at least in the present time. In both cases, the promise of a thoroughly modern and ideal space relies entirely on language, as though it suffices for a change on a practical level. Language features as a magic instrument; to say is to act, to name is to create or alter a given reality. This mechanism can work only to a certain point, without forcing too much the idea of a possible world. The collective imagination that language activates is founded on what Bertrand considers an innovation rather than an invention: the difference lies in the pragmatic nature of the first one since the imagination must, in any case, set itself in a realistic socio-economic context. In effect, to avoid perturbing the globalized ideal grounded on the elites' economic interests, the new must not be entirely new but, at least, partly familiar and recognizable.

This last aspect was indispensable for the Irish's new place in the changing society of Northern Ireland, as the figurative stability of the traditional font could guarantee an almost immediate recognition of the identity status. The functioning of every myth necessitates, after all, an established collective imagination, even more so in cases where it is imperative to produce or reactivate the values needed for a drastic change in the socio-economic milieu. Working like the mythomoteur, which is intrinsically dynamic, the concept of mythe projectif entails a similar future orientation. For its assimilation, it needs to be rooted in an imaginary past whose mythical essence is widely acknowledged. Paris must still be recognizable as Paris. If promoting the innovation of the ultramodern capital city, like Irish, it must be identified as Irish, a specific language yet able to rethink itself fashionably. The ideological move that makes a myth so efficacious relies on some primal narratives' reactivation in a new environment. This attests to the difficulty of imagining a logic other than a patrimonial one, where dominates the value of a supposed authenticity and the obsession with the past (Leone 2019). 
The sharing of memory, of a shared past, brings the institution of a collectiveness that the mythic narratives' circulation fosters. A myth circulates in society as an indispensable element to forge a political or identity imagery, as Bernard Lamizet (2019) notes, underlining its role in community-building. Media are the means typically employed to diffuse or even forge the collective myths in the public space. The narratives of the urban campaign for the renovation of Paris or the Belfast streets' murals can be considered, respectively, as a particular type of media or media-like agents. A community's capability to represent itself is a fundamental point in creating or maintaining social cohesion, both at the local and the national level. Similar strategies can be successfully deployed both by state authorities and by local groups on a much smaller scale, confirming that the ideological apparatus is flexible enough to adapt to different contexts.

This result can be read as the effect of a reality in which local and global tend to flow into each other, what previously, following the suggestions of Siun Carden, has been defined as that glocal tendency, so common in the worldwide economic system. This interpretation is particularly important for the promotion of another way of understanding the post-conflict society of Northern Ireland and its way of dealing with how to forget/ remember the past. The use of Irish on the walls exemplifies the murals as a local and global synthesis, as Debbie Lisle (2006) has suggested. Whether in opposition or in combination with the widespread interpretation that takes murals as local symbols, another understanding has emerged, proposing that murals should be read in a broader frame, allowing for their tourist promotion and dialog with other events worldwide.

Although controversial, this glocal aspect of the more recent phase of post-Troubles Northern Ireland represents a significant step towards containing the country's persisting sectarian attitudes, evident also in the urban structure of Belfast and its longstanding walls (McAtackney 2018) and the cross-community policy for coping with division (Hargie and Dickson 2003). Lisle, citing Neil Jarman's observations about the importance of media in representing the murals, underlines their ability to provide a specific globally shared Belfast scenario, capable of creating an idea of the 'authentic' city on a worldwide scale. From simple images like the ones depicted on postcards to the fashionable practice of taking personal photos or selfies with pieces of landscapes in the background, this visual material is perceived as proof of the tourist's place (Papadaki 2019). This openness of the image to the global networks again comprises a branding strategy, obeying specific ideological motivations that power elites and communities skillfully manage. From the start, Northern Ireland's murals have acquired monuments' status due to their reflexive and complex function of representativeness. They are strategically conceived and used, mainly by the Republicans, who grew more aware of and sensitive to the power images, narratives, and even their bodies are liable 
to trigger since the 1981 Hunger Strike (see McAtackney 2014). No less than the City Council's efforts, muralism tried to impose its own voice in the historical debate, nowadays reinforced by the tourist interest and its economic consequences. Understanding the murals' value in the new Northern Ireland tourist routes demands acknowledging their place in the global market and how local stories can reinvent themselves in it. Future research must be fully aware of the ideological interplay between the center and the predominantly working-class areas of Belfast and contextualize memory discourse in a way that involves both communities and the State.

\section{References}

Augé, Marc 1992. Non-lieux. Introduction à une anthropologie de la surmodernité. Paris: Le Seuil.

Barthes, Roland 1957. Mythologies. Paris: Éditions du Seuil.

Baudrillard, Jean 1981. Simulacres et simulation. Paris: Galilée.

Bellentani, Federico 2017. Connecting semiotics and cultural geography: a framework for the interpretations of monuments and memorials. Cross-Inter-Multi-Trans (Proceedings of the 13th World Congress of the International Association for Semiotic Studies [IASS / AIS]), Kaunas, 206-215.

Benveniste, Émile 1970. L'appareil formel de l'énonciation. Langages 17:12-18. Available from: https: / / bit.ly / 37iswGu [accessed January 20, 2020].

Bertrand, Denis 2019. Mythe et réinvention. In: Basso, P., Bertrand, D. and A. Zinna (eds.) Utopies et formes de vie. Mythes, valeurs et matières. Hommage à Paolo Fabbri. Toulouse: Éditions CAMS/O, Collection Actes, 91-104.

Bollens, Scott A. 2012. City and Soul in Divided Societies. Oxford and New York: Routledge.

Carden, Siun 2017. The Gaeltacht Quarter of Mural City: Irish in Falls road murals. In: Skinner, Jonathan and Lee Jolliffe (eds.) Murals and tourism. Heritage, politics and identity. London and New York: Routledge, 236-253.

Crooke, Elizabeth and Maguire, Tom (eds.) 2019. Heritage after conflict. Northern Ireland. London and New York: Routledge.

Feldman, Allen 1991. Formations of violence. The narrative of the body and political terror in Northern Ireland. Chicago and London: The University of Chicago Press.

Forker, Martin and Jonathan McCormick (eds.) 2009. Walls of history: the use of mythomoteurs in Northern Ireland murals. Irish Studies Review 17(4): 423-465. Available from: https: / / bit.ly/3jRr7Mj [accessed January 20, 2020].

Hargie, Owen and Dickson, David (eds.) 2003. Researching the troubles. Social science perspectives on the Northern Ireland conflict. Edinburgh and London: Mainstream Publishing. 
Huyssen, Andreas 2003. Present Pasts: Urban Palimpsests and the Politics of Memory. Stanford: Stanford University Press.

Jakobson, Roman 1960. Linguistics and poetics. In: Sebeok, Thomas A. (ed.) Style in language. New York: John Wiley and Sons, Technology Press of the Massachusetts Institute of Technology, 350-377.

Jarman, Neil 1997. Material conflicts: Parades and visual displays in Northern Ireland. Oxford: Berg.

Jauss, Hans R. 1982. Toward an Aesthetic of Reception. Trans. by Timothy Bahti. Minneapolis: University of Minnesota Press.

Kennedy-Pipe, Caroline 1997. The origins of the present troubles in Northern Ireland. London and New York: Longman.

Lamizet, Bernard 2019. Sémiotique de l'imaginaire politique. In: Basso, P., Bertrand, D. and A. Zinna (eds.) Utopies et formes de vie. Mythes, valeurs et matières. Hommage à Paolo Fabbri. Toulouse: Éditions CAMS/O, Collection Actes, 33-52.

Leone, Massimo 2019. Turismo narrativo: per una semiotica della reviviscenza culturale. EC (e-journal of the AISS, Associazione Italiana Studi Semiotici), online. Available from: http: / / www.ec-aiss.it [accessed August 02, 2020].

Lisle, Debbie 2006. Local Symbols, Global Networks: Rereading the Murals of Belfast. Alternatives (31): 27-52.

Malinowski, Bronislaw 1923. The problem of meaning in primitive languages. In: Ogden, Charles K. and Ivor A. Richards (eds.) The meaning of meaning. London: Kegan Paul, Trench and Trubner, 296-336.

Mazzucchelli, Francesco 2010. Urbicidio: il senso dei luoghi tra distruzioni e ricostruzioni nella ex Jugoslavia. Bologna: Bononia University Press.

McAtackney, Laura 2011. Peace maintenance and political messages: the significance of walls during and after the Northern Irish 'Troubles'. Journal of social archaeology 11 (1): 77-98.

McAtackney, Laura 2014. An archaeology of the Troubles: the dark heritage of Long Kesh/Maze prison. Oxford: OUP.

McAtackney, Laura 2018. The many forms and meanings of (peace) walls in contemporary Northern Ireland. Review of International American Studies 11 (1): 39-61.

Moore, Robert 2016. Rebranding Belfast: Chromatopes of (Post-) Conflict. Signs and Society (4): 138-162.

Nora, Pierre 1989. Between Memory and History: Les Lieux de Mémoire. Representations (26), Special Issue: Memory and Counter-Memory, 7-24.

Papadaki, Eirini 2019. Mediating mediations of the past: Monuments on photographs, postcards and social media. Punctum. International Journal of Semiotics 5(2), Special issue on Semiotics of Monuments: Politics \& Form from the 20th to the 21st century, 134-154. 
Rigney, Ann 2018. Remembrance as remaking: memories of the nation revisited. Nations and Nationalism 24 (2): 240-257.

Skinner, Jonathan and Lee Jolliffe (eds.) 2017. Murals and tourism. Heritage, politics and identity. London and New York: Routledge.

Smith, Anthony D. 1986. The ethnic origins of nations. Oxford: Basil Blackwell.

\section{AUTHOR}

Gabriella Rava Ph.D. candidate in Semiotics and Philosophy of communication, Department of Humanities, Charles University, Prague, Czech Republic. 


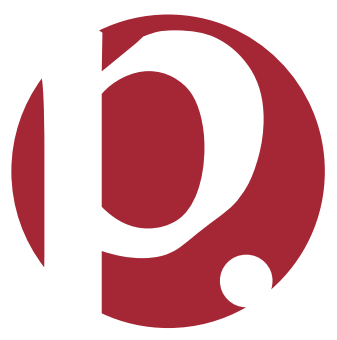

